\title{
Reproductive characteristics of the polymorphic Caribbean reef building coral Montastrea annu- laris. I. Gametogenesis and spawning behavior
}

\author{
Manfred L. J. Van Veghel ${ }^{1,2}$ \\ ${ }^{1}$ CARMABI Foundation - Ecological Institute, PO Box 2090, Curaçao, Netherlands Antilles \\ ${ }^{2}$ University of Amsterdam, Institute of Taxonomic Zoology, PO Box 4766, 1009 AT Amsterdam, The Netherlands
}

\begin{abstract}
The dominant Caribbean reef coral Montastrea annularis (Ellis \& Solander) exists as at least 3 morphotypes of uncertain taxonomic status. I examined reproductive characteristics of the morphotypes (viz. 'Bumpy', 'Massive' and 'Columnar'; Van Veghel \& Bak 1993, Mar. Ecol. Prog. Ser. 92: 255-265) histologically and studied spawning in the field. The morphotypes all had the same reproductive mode, i.e. individuals were hermaphrodites, gametogenesis was synchronized, and both eggs and sperm matured within the same gonad and were broadcast on the same lunar phases for external fertilization. Spawning in the field on Curaçao took place 6,7 and/or $8 \mathrm{~d}$ after full moon in September and October. No differences in spawning time and/or behavior were observed. Gametogenic initiation and spawning took place about 1 mo later on the reefs of Curaçao and Bonaire than in most other Caribbean localities. Possible spawning timing cues such as relative seawater temperature, moon phase, and time after sunset were found to be consistent with other spawning observations of this species; tidal regime was not consistent.
\end{abstract}

KEY WORDS: Reproduction · Gametogenesis · Spawning · Corals · Caribbean · Montastrea annularis . Polymorphism

\section{INTRODUCTION}

Mass spawning activities of scleractinian corals have received much public and scientific attention since the extent of this phenomenon became known (Harrison et al. 1984, Babcock et al. 1986). Spawning observations are numerous from Pacific reefs (Harrison \& Wallace 1990), whereas the first field observations in the Caribbean became available only recently (Wyers et al. 1991, Gittings et al. 1992, Van Veghel 1993). Hypotheses on the major cues (e.g. water temperature, tidal and lunar patterns, day-night rhythm) which may influence the synchronization of gametogenesis and spawning time have been discussed in several papers (Fadlallah 1983, Jokiel 1985, Babcock et al. 1986, Harrison \& Wallace 1990, Richmond \& Hunter 1990, Wyers et al. 1991). However it is still not known if major cues are of environmental and/or genetic origin, a general phenomenon, or species specific.
The reproductive biology of the dominant Caribbean reef building coral Montastrea annularis (Ellis \& Solander) has been intensively studied (Szmant-Froelich 1985, Szmant 1986, 1991, Soong 1990, 1991, Szmant \& Gassman 1990, Wyers et al. 1991, Van Veghel \& Bak 1994, Van Veghel \& Kahmann 1994). Recent studies on electrophoretic, morphological and behavioral aspects of $M$. annularis populations from Curaçao and Bonaire (Van Veghel \& Bak 1993) and Panama (Knowlton et al. 1992) suggest that this species consists of at least 3 distinct morphs: viz. 'Bumpy', 'Massive' and 'Columnar' (Van Veghel \& Bak 1993, Weil \& Knowlton 1994). To examine differences between the morphs, I studied gametogenesis and spawning behavior (this paper), fecundity and colony structure (Van Veghel \& Kahmann 1994) and reproduction in damaged and regenerating colonies (Van Veghel \& Bak 1994).

Gametogenesis was studied over a 2 yг period using histological methods to examine differences in gamete 


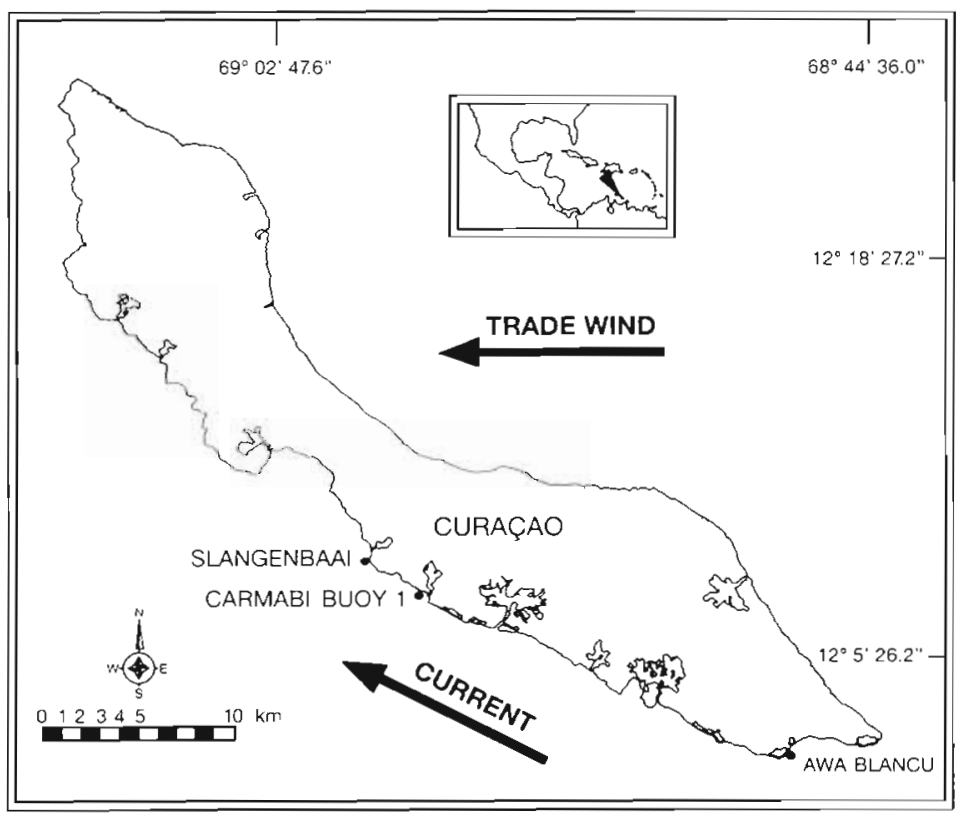

Fig. 1 Locations of the 3 sampling stations on Curaçao, Netherlands Antilles

development and maturation of the 3 morphotypes. A nocturnal reef monitoring programme was organized to examine spawning time and behavior. Data on possible cues influencing reproductive synchronization were collected and are compared with other Montastrea annularis spawning observations.

\section{MATERIALS AND METHODS}

Gametogenesis. From July 1990 to September 1992 samples were collected to study the reproductive status of the 3 Montastrea annularis morphotypes. Five samples from different colonies of each morphotype were collected on each date at 3 locations on the leeward coast of Curaçao (Netherlands Antilles): i.e. Awa Blancu, CARMABI Buoy 1 and Slangenbaai (Fig. 1; Bak 1975, Van Duyl 1985, Van Veghel \& Bak 1993). During reproductive periods collections were intensified from monthly to biweekly or weekly (total of 34 sampling dates).

Samples (ca $20 \mathrm{~cm}^{2}$ ) were collected haphazardly from the centers of mature colonies $\left(>300 \mathrm{~cm}^{2}\right)$ with a hammer and chisel (Van Veghel \& Kahmann 1993). Samples were temporarily stored in seawater and processed in numbered mosquito-gauze bags. Processing included fixation for 24 to $48 \mathrm{~h}$ in Bouin's fixative and rinsing with running tap-water for 12 to $24 \mathrm{~h}$ before decalcification with a formic acid and sodium citrate treatment (Rinkevich \& Loya 1979). Processing for histological examination followed standard techniques
(Burck 1966, Delvoye 1988); sections were stained with Harris Hematoxylin, Eosine and Orange G (Burck 1966). Both transverse and longitudinal sections ( 6 to $10 \mu \mathrm{m}$ thick) were examined.

Reproductive development. When present, the development stage of gametocytes was determined according to standard criteria (Balinsky 1975, Bloom \& Fawcett 1975, Delvoye 1988) (Fig. 2). To study gametogenic timing, samples of 3 reproductive seasons and 3 localities were combined and arranged by the number of weeks around the day major spawning was observed $\left(t_{0}=7 \mathrm{~d}\right.$ after the full moon in September of that year). An average of 8 samples per morphotype per data point were analyzed. Differences in frequency distributions of the described development stages were tested using a KolmogorovSmirnov 2-sample test (Sokal \& Rohlf 1981).

Spawning observations. Based on Szmant's (1991) predictions a nocturnal monitoring programme was organized on potential Montastrea annularis spawning nights. At Slangenbaai a $260 \mathrm{~m}$ long underwater trail, consisting of 284 numbered $M$. annularis colonies at depths between 5 and $15 \mathrm{~m}$, was used to monitor spawning. Monitoring took place the first $5 \mathrm{~d}$ following the full moons of August (26th) and September (23rd) 1991, between about 20:30 and 22:30 h. Subsequently Days 6, 7 and 8 were monitored between about 18:00 and 01:00 h. In October the reef was monitored on Days 6,7 and 8 after the full moon (23rd) between about 21:00 and 23:00 h. About 75 divers assisted in underwater observations. If spawning was observed the divers recorded the colony identification number and spawning time. Additional observations on spawning behavior were recorded by the author, participating scientists and students. In 1992 and 1993 additional spawning observations were made to confirm earlier results.

Environmental cues. Data on possible environmental cues, i.e. seawater temperature trend, moon phase, spawning time after sunset, and tidal regime (Curaçao Port Authorities), were examined. Comparisons were made with data available from Montastrea annularis spawning observations at other geographic localities: Bahamas, Bermuda and Puerto Rico. Mean seawater temperatures for 1980 to 1990 (Goreau et al. 1991) were compared with the effective solar energy $(E)$ (see also Delvoye 1988) at the various geographic localities, calculated as:

$$
\begin{aligned}
E=\cos & \left\{\left[90^{\circ}\left(90^{\circ}-\text { solar altitude }\right)\right.\right. \\
& \left.+ \text { declination }]\left(\pi / 180^{\circ}\right)\right\}
\end{aligned}
$$

using data from List (1951). 

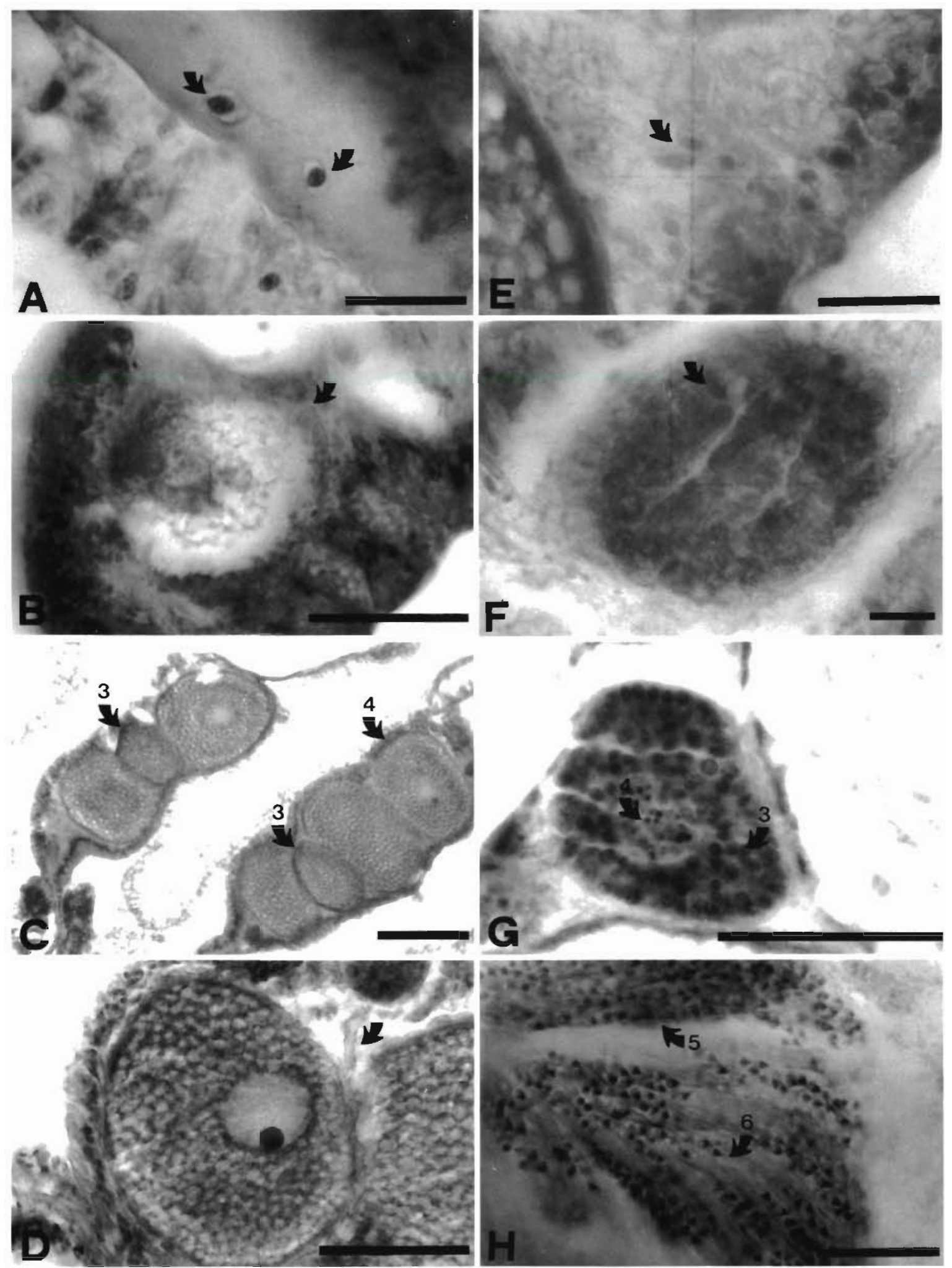

Fig. 2. Montastrea annularis. Photomicrographs of (A to D) oogenic and (E to $H$ ) spermatogenic development. (A) Stem-cells (stage 1) situated in the mesenterial gastrodermis. (B) Oogonia (stage 2). (C) Oocyte I (stage 3) and Oocyte II (stage 4). (D) Mature ova (stage 5); arrow points to vitelline membrane. (E) Stem-cells (stage 1); notice part of oocyte in the left corner. (F) Spermatogonia (stage 2). (G) Primary (stage 3) and secondary (stage 4) spermatocytes. (H) Spermatids (stage 5) and spermatozoa (stage 6 ). Scale bars: A, B, E, H = $10 \mu \mathrm{m} ; \mathrm{C}, \mathrm{D}, \mathrm{F}, \mathrm{G}=100 \mu \mathrm{m}$ 

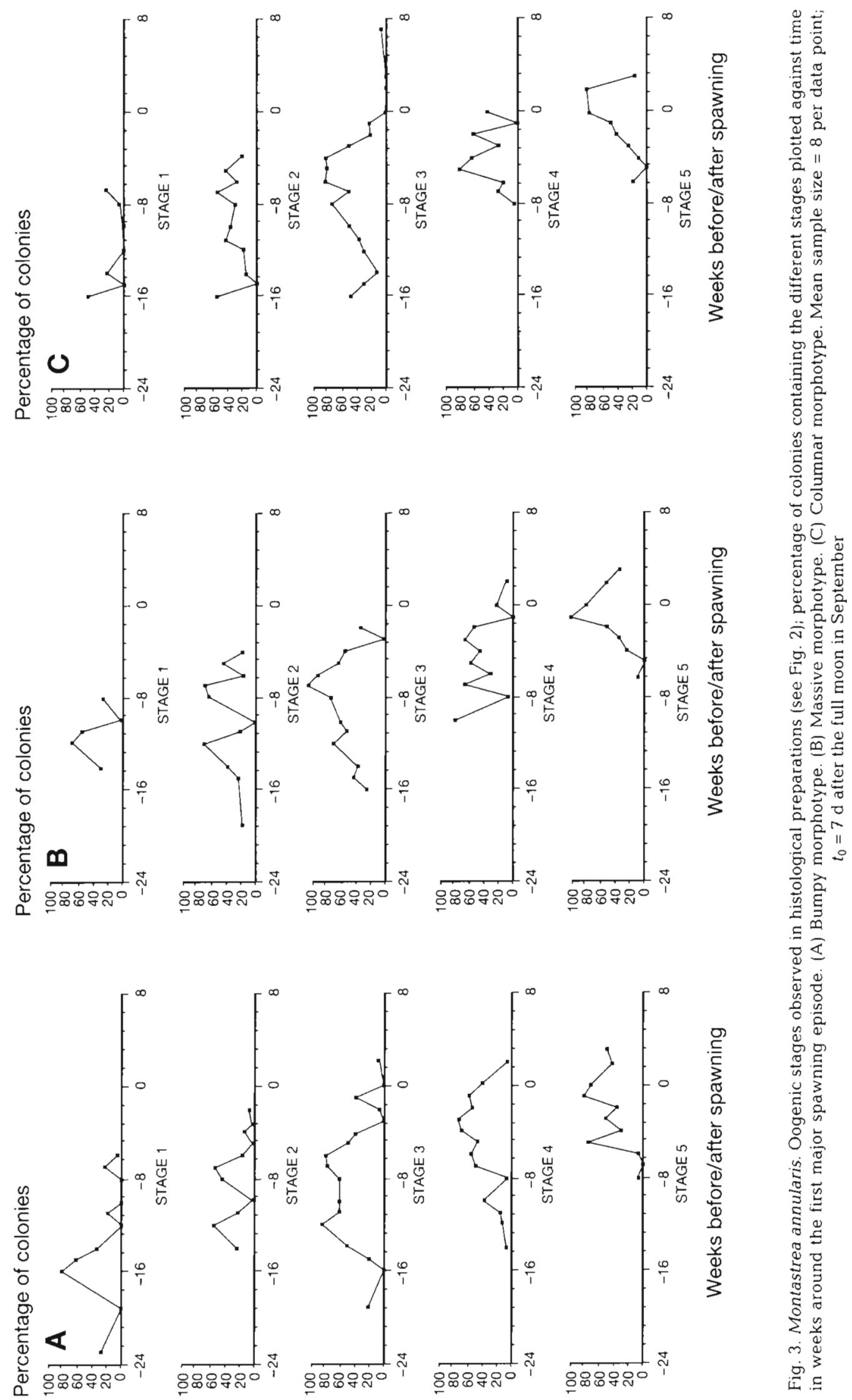

0
$\frac{1}{1}$
3
0
0
0
0
$\frac{1}{4}$
$\frac{1}{0}$
0
0
0
0
0
0
0
0
0
3

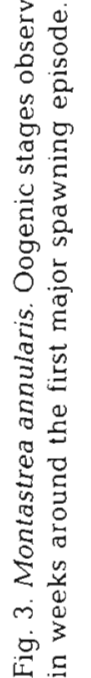




\section{RESULTS}

\section{Gametogenesis}

All 3 morphotypes of Montastrea annularis are hermaphroditic with oocytes and spermaries intermingled within 1 gonad. Only in 1 colony, of the 612 individuals examined, was sperm observed in the absence of eggs The first gametes or stem-cells out of which gametes could proliferate were found approximately $20 \mathrm{wk}$ before the first major spawning event. Seven weeks after this event no more gonads were found, except for 1 columnar individual which possessed 1 degenerated oocyte. During the rest of the year, from the end of October through end of May, no reproductive tissue was found.

Oogenesis. Development of female gametes on Curaçao was obvious by the end of May (Fig. 3), while the first mature eggs could be observed 6 to $8 \mathrm{wk}$ before the first major spawning period. During this period female gonads increased from about $4 \mu \mathrm{m}$ $(n=38)$ to an average of $225 \mu \mathrm{m}(\mathrm{n}=1665)$ for mature ova (see Fig. 5).

Spermatogenesis. Spermatogenesis (Fig. 4) started when developing eggs reached stage 3 and/or 4 which is about $10 \mathrm{wk}$ before the major spawning event Mature spermaries did not occur until 1 wk before spawning. The maximum percentage of colonies carrying mature sperm was $32 \%(n \geq 15)$.

Increase in egg size (Fig. 5) and development stages of both eggs and sperm of the morphotypes studied showed similar trends and were not significantly different (Kolmogorov-Smirnov 2-sample test).

\section{Mass spawning observations}

Spawning time. In spite of the expected spawning 1 wk after the full moon of August and September, spawning was observed 6,7 and $8 \mathrm{~d}$ following the full moon in September and a second less massive episode occurred 6 and $7 \mathrm{~d}$ after the full moon in October 1991. The first $2 \mathrm{~d}$ of spawning were the most intense: about $10 \%$ of the marked colonies spawnedi during other days it was $2 \%$ or less. In 1992 a major spawning episode was observed 5, 6, and $7 \mathrm{~d}$ after the full moon in September; spawning was less intense $7 \mathrm{~d}$ after the full moon in October. The full moon in 1993 was very late in the month; the first and minor spawning episode was 6,7 and $8 \mathrm{~d}$ following the 31 August full moon, and the most intense period 6 and $7 \mathrm{~d}$ after the full moon on 30 September. Individuals were observed spawning pink eggsperm bundles on different days both in the first and second episodes.
Spawning behavior. The Montastrea annularis spawning behavior is similar to the Type 1 spawning behavior described by Babcock et al. (1986), a slow release of gamete bundles through the polyp mouth. Five different spawning stages were distinguished:

(1) 'Setting stage' (Babcock et al. 1985): just prior to spawning, egg-sperm bundles become visible beneath the oral disk;

(2) 'Birth stage': egg-sperm bundles are squeezed through the polyp mouth;

(3) 'Gliding stage': egg-sperm bundles dance near the mother colony (Fig. 6);

(4) 'Upward stage': upward movement of the eggsperm bundles;

(5) 'Bursting stage': egg-sperm bundles are mixed in the upper water layer and fall apart.

Simultaneous spawning took place for a group of 10 up to hundreds of connected polyps, but usually not for the whole colony at once. Time between stages 1 and 2 could be up to $20 \mathrm{~min}$. Stage 3 took 1 or a few minutes; gamete bundles were first neutrally buoyant and after that they slowly drifted to the surface. Stage 5 was usually reached within about $1 \mathrm{~h}$.

Environmental cues. Fig. $7 \mathrm{~A}$ illustrates that spawning on Curaçao (lat. $12^{\circ} \mathrm{N}$ ) correlated to the period of highest seawater temperature. This can also be concluded for other Caribbean locations (Table 1, Fig. 7A): Bahamas (lat. $25^{\circ} \mathrm{N}$ ), Bermuda (lat. $32^{\circ} \mathrm{N}$ ) and Puerto Rico (lat. $18^{\circ} \mathrm{N}$ ). Seawater temperature starts increasing in March for all locations (Fig. 7A). This corresponds to the month in which the effective solar energy increases above the annual average level: $94 \%, 87 \%$, $82 \%$ and $92 \%$ for Curaçao, the Bahamas, Bermuda and Puerto Rico, respectively (Fig. 7B). In June and July the seawater temperature decreases in Curaçao as a consequence of a decrease in effective solar energy (Fig. 7A, B).

Timing of spawning on Curaçao was consistent in relation to the moon phases, approximately $1 \mathrm{wk}$ after the full moon. Further, it took place between 21:00 and 23:00 h, approximately 2 to $3 \mathrm{~h}$ after sunset, when tides fell (Fig. 8) and differences between high and low tide were moderate.

Reproductive isolation. About $22 \%$ of the marked colonies were observed spawning synchronously, including all 3 morphotypes. Morphotypes did not differ in spawning time and behavior.

Observations of other reef organisms spawning in this observation period are listed in Van Veghel (1993).

\section{DISCUSSION}

Life history and genetic data of sympatric Montastrea annularis morphotypes recently gave reason to 


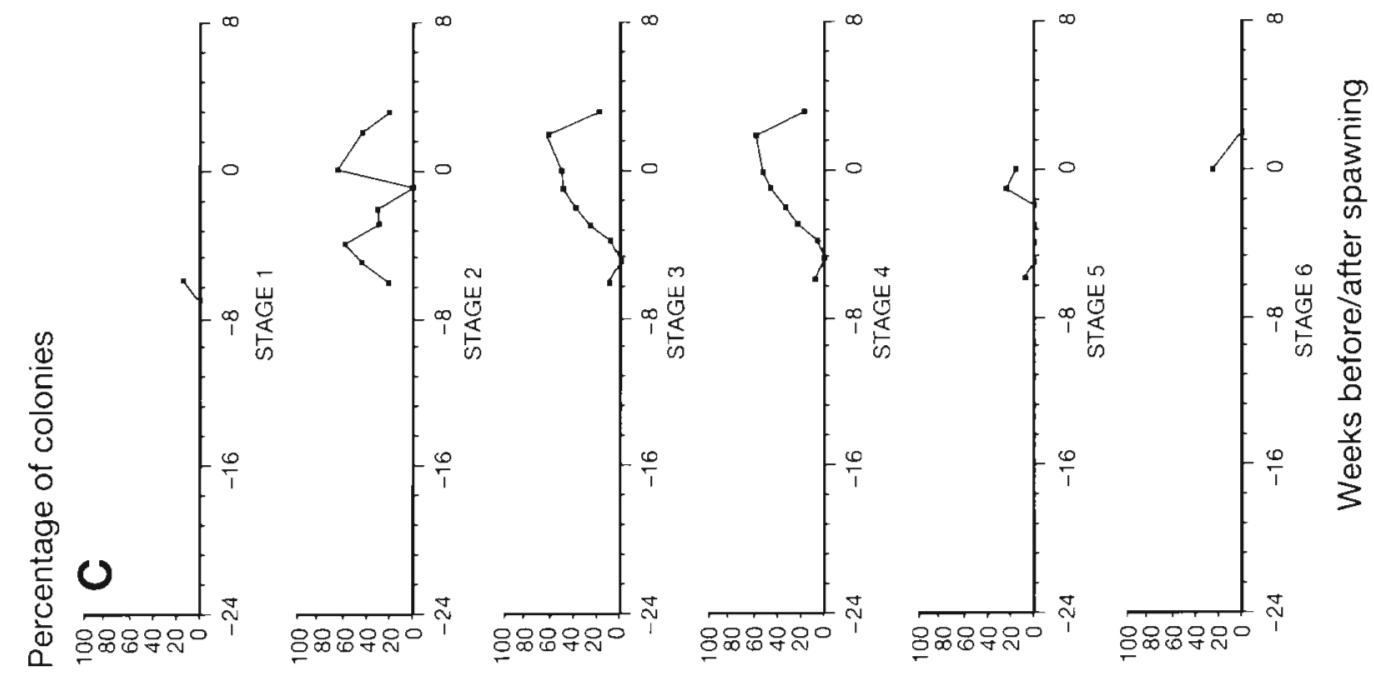

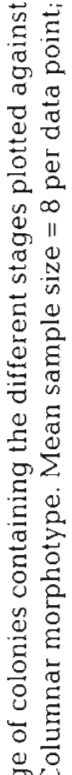

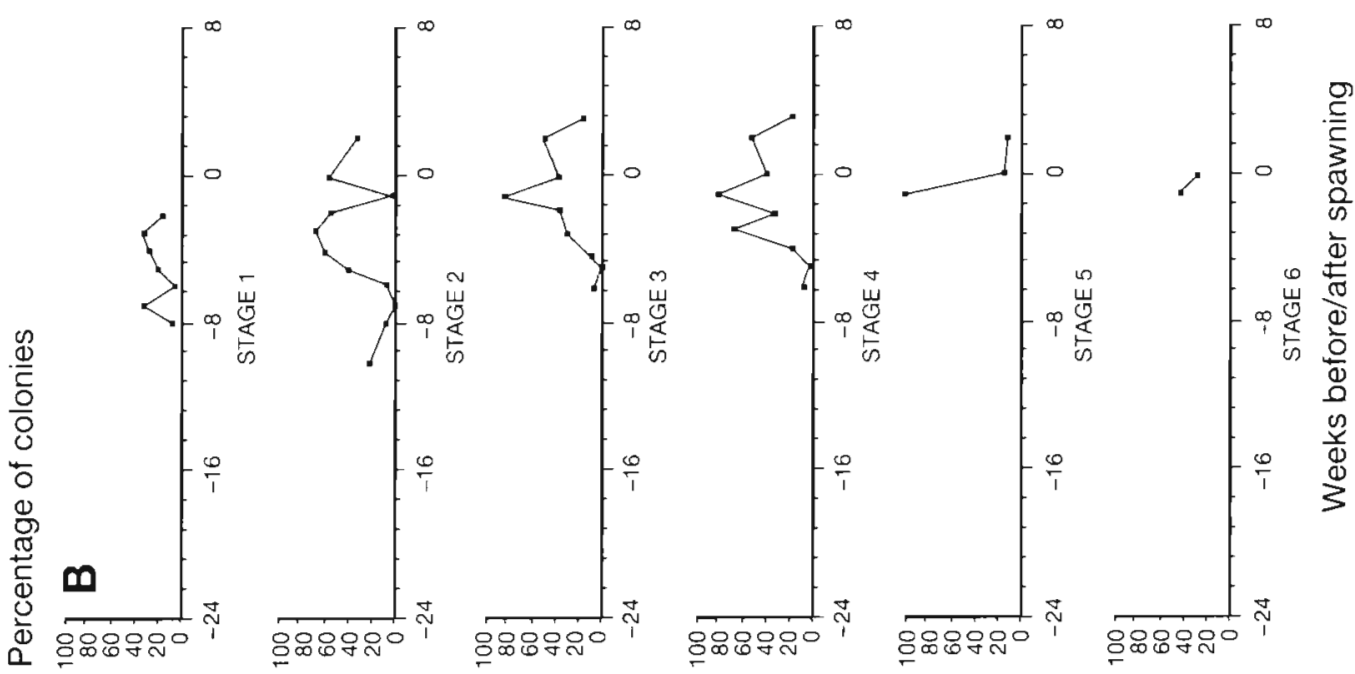

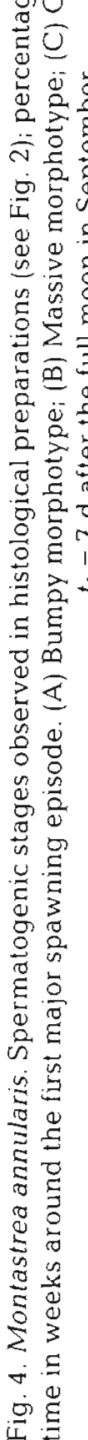

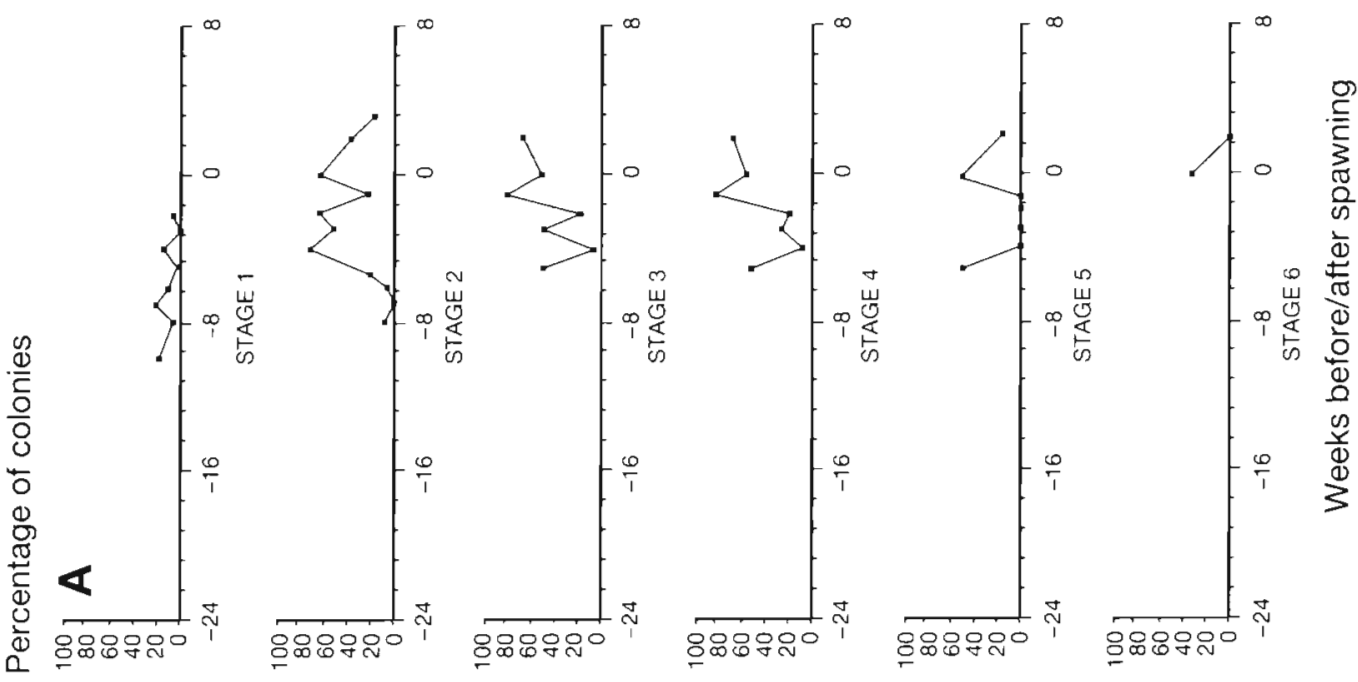




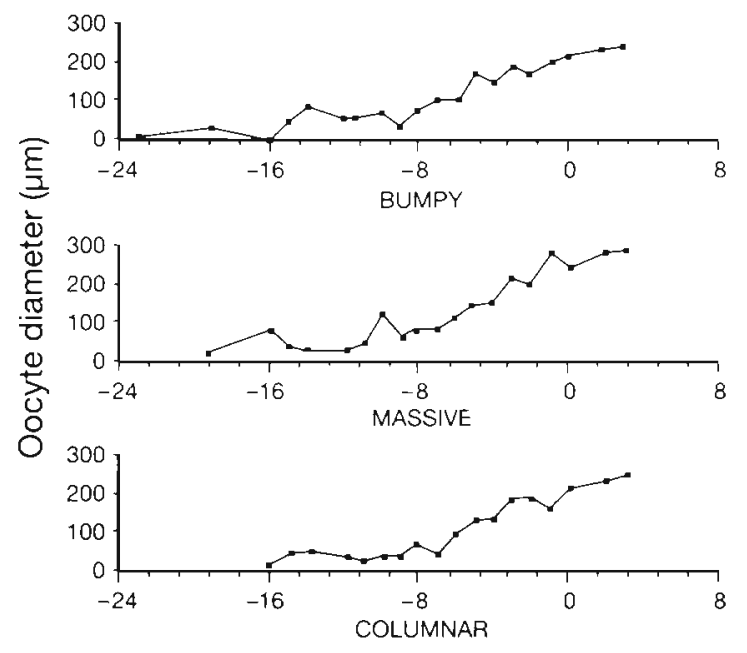

Weeks before/after spawning

Fig. 5. Montastrea annularis. Increase in ova maturation of different morphotypes. Oocyte diameter (in $\mu \mathrm{m}$ ) plotted against time in weeks around the first spawning episode Sample size varies per stage, $38<\mathrm{n}<1665$

question the taxonomic status of this dominant Caribbean reef building coral species (Knowlton et al. 1992, Van Veghel \& Bak 1993). The potential use of $M$. annularis as a biological monitoring species on Atlantic reefs (Ogden \& Gladfelter 1986, Tomascik 1990) requires a proper description of differences in life history aspects of the described morphotypes and clarity about their taxonomic status. Although coral taxonomy is based on the morphological distinctness of species, I examined potential pre-mating isolating mechanisms (mode or timing of reproduction and spawning behavior) which are used as criteria for speciation in the biological species concept

No potential mechanism in reproductive isolation of the studied Montastrea annularis morphotypes (Van Veghel \& Bak 1993) was found in their reproductive strategy. All 3 morphotypes had a comparable reproductive mode, gametogenesis was synchronized and gametes matured at the same lunar phases. Also spawning time and behavior showed no differences. This leaves the possibility of post-mating reproductive isolation (gametic mortality, zygotic mortality, hybrid inviability or sterility; see Mayr 1970) as potential isolating mechanisms. A pilot study on cross fertilization success failed because all the individuals spawning were of the Bumpy morph.

Pre-mating isolation mechanisms have been used in coral taxonomy. Van Moorsel (1983) suggested that the Agaricia agaricites humulis (Verrill) morph was a different species because of its different reproductive mode: seasonal instead of continuous planulation. Gametogenesis in Pocillopora damicornis (Linneaus) morphotypes was synchronized but gametes matured

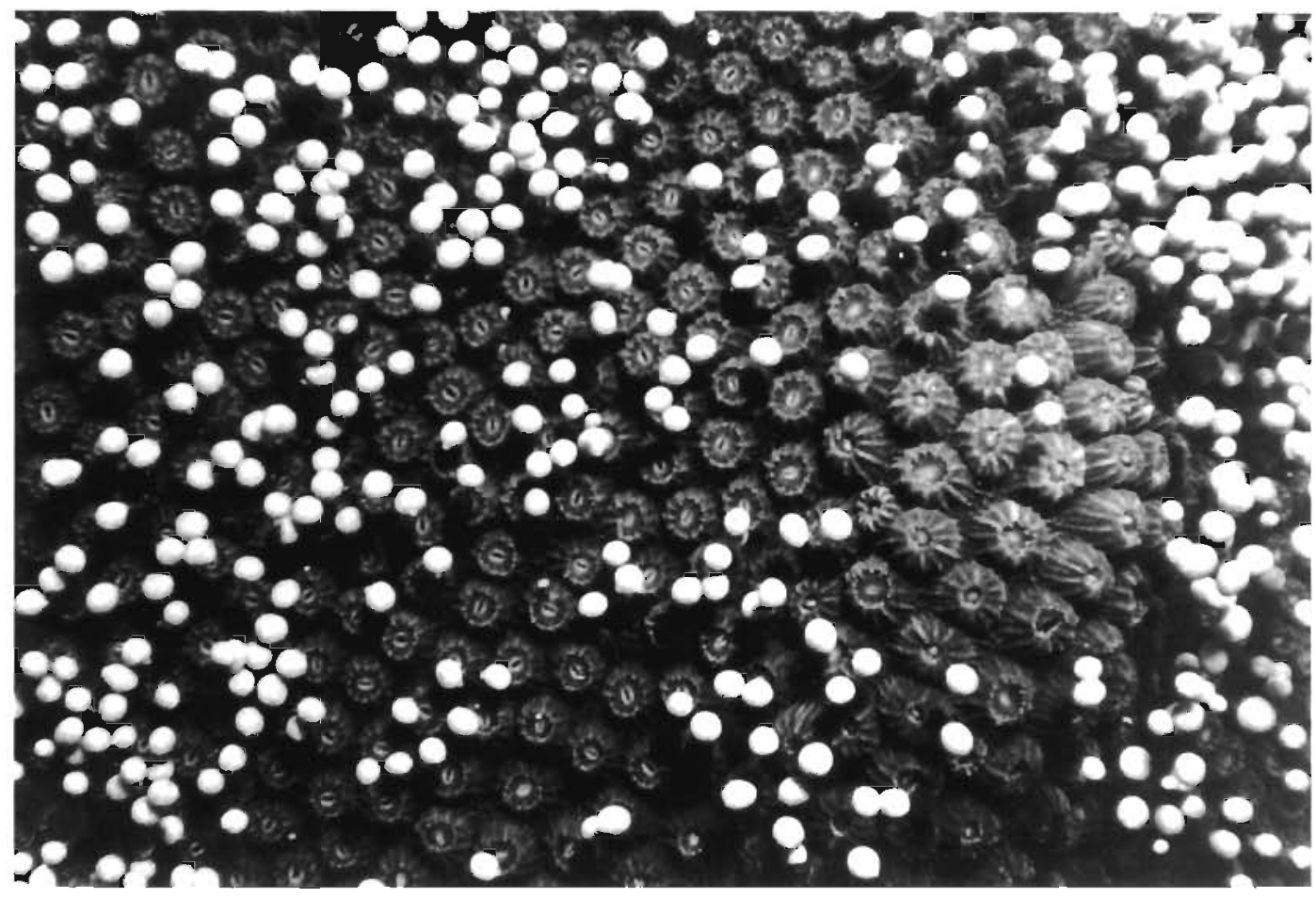

Fig. 6. Montastrea annularis. Spawned egg-sperm bundles just after being released from a Massive morphotype at location Slangenbaai. Curaçao, September 1991; magnification ca $2.5 \times$ 
Table 1. Montastrea annulanis. Review of reported spawning observations at days or weeks after full moon (FM), including underwater (Field), laboratory (Lab.) and histological (Histol.) observations

\begin{tabular}{|c|c|c|c|c|c|c|c|}
\hline Locality & Year & Month 1 FM & Days after FM & Month 2 FM & Days after FM & Method & Source $^{a}$ \\
\hline Puerto Rico & 1983 & Aug & $1 \mathrm{wk}$ & Sep & $1 \mathrm{wk}$ & Histol. & 1 \\
\hline Puerto Rico & 1984 & Aug & $1 \mathrm{wk}$ & Sep & $1 \mathrm{wk}$ & Histol. & 1 \\
\hline Bermuda & 1985 & Aug & $5-10 d$ & Sep & $5-10 d$ & Lab. & 2 \\
\hline Bermuda & 1986 & Jul & $4-9 d$ & Aug & $8-11 d$ & Lab./Field & 2 \\
\hline Panama & 1987 & Aug & $1 \mathrm{wk}$ & Sep & $1 \mathrm{wk}$ & Histol. & 3 \\
\hline Panama & 1988 & Aug & $1 \mathrm{wk}$ & Sep & $1 w k$ & Histol. & 3 \\
\hline Curaçao & 1990 & Sep & $1 \mathrm{wk}$ & Oct & $1 \mathrm{wk}$ & Histol. & 4 \\
\hline Bahamas & 1991 & Aug & $7-8 d$ & & & Field & 5 \\
\hline Gulf of Mexico & 1991 & Aug & $7 \mathrm{~d}$ & & & Field & 6 \\
\hline Curaçao & 1991 & Sep & $6,7,8 d$ & Oct & $6,7 \mathrm{~d}$ & Field & 4 \\
\hline Florida & 1992 & Aug & $7,8 \mathrm{~d}$ & & & Lab. & 5 \\
\hline Gulf of Mexico & 1992 & Aug & $7,8 \mathrm{~d}$ & & & Field & 7 \\
\hline Bonaire & 1992 & Sep & $3,6,7 \mathrm{~d}$ & & & Field & 8 \\
\hline Curaçao & 1992 & Sep & $5,6,7 \mathrm{~d}$ & Oct & $7 \mathrm{~d}$ & Field & 4 \\
\hline Curaçao & 1993 & Sep & $6,7,8 \mathrm{~d}$ & Oct & $6,7 \mathrm{~d}$ & Field & 4 \\
\hline Saba & 1993 & Sep & 8 & & & Field & 9 \\
\hline
\end{tabular}

at different lunar phases, so that the morphs were also suggested to be reproductively isolated (Muir 1984). Recent data, however, indicated that a phylogenetic species concept may be more appropriate than the biolagical species concept for scleractinian corals (Willis et al. 1992). Fertilization trials in that study resulted in hybridization between species from different genera, while no fertilization occurred between 2 morphs of the same species. Data on $P$. damicornis suggested different reproductive modes at different localities (Ward 1992). Sexual reproduction in scleractinian corals seems to be complex; knowledge is needed, especially on the interbreeding potential between and within corals.

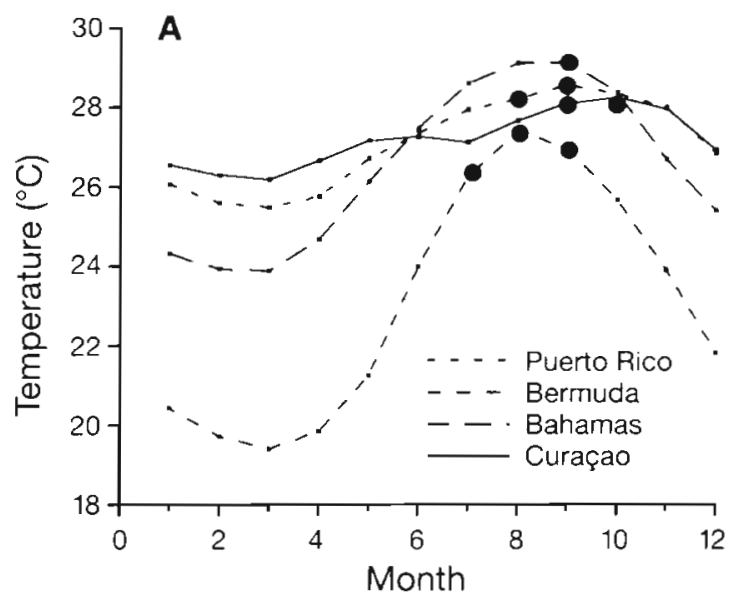

Spawning of Montastrea annularis was thought to be synchronous over its geographical range, in spite of the differences in annual temperature and light cycle (Szmant 1991). However, since more data have been available it appears that spawning is not uniform; populations on Bermuda tend to have their major spawning episode in July (Wyers et al. 1991) versus September in Curaçao. Most other $M$. annularis spawning observations were from August (Szmant 1991, Gittings et al. 1992). Geographic differences in spawning time are also described for the free-living Caribbean coral Manicina areolata (Linneaus) (Johnson 1992). It seems that $M$. annularis spawning is linked with seawater temperature, since all events took place during the

Fig. 7. Montastrea annularis. (A) Spawning observation plotted against monthly mean of annual sea surface temperature and (B) theoretical curve of effective solar energy for the Caribbean locations: Curaçao $\left(12^{\circ} \mathrm{N}\right)$, Bahamas $\left(25^{\circ} \mathrm{N}\right), \mathrm{Bermuda}\left(32^{\circ} \mathrm{N}\right)$ and Puerto Rico $\left(18^{\circ} \mathrm{N}\right)$.

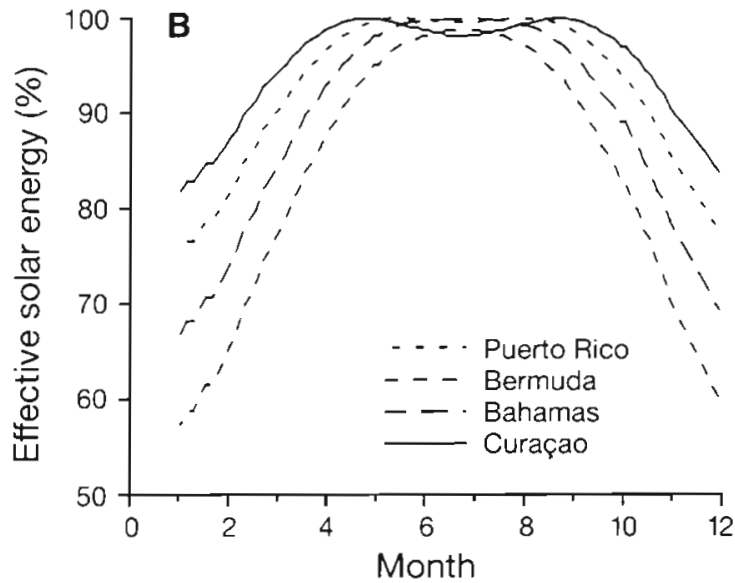




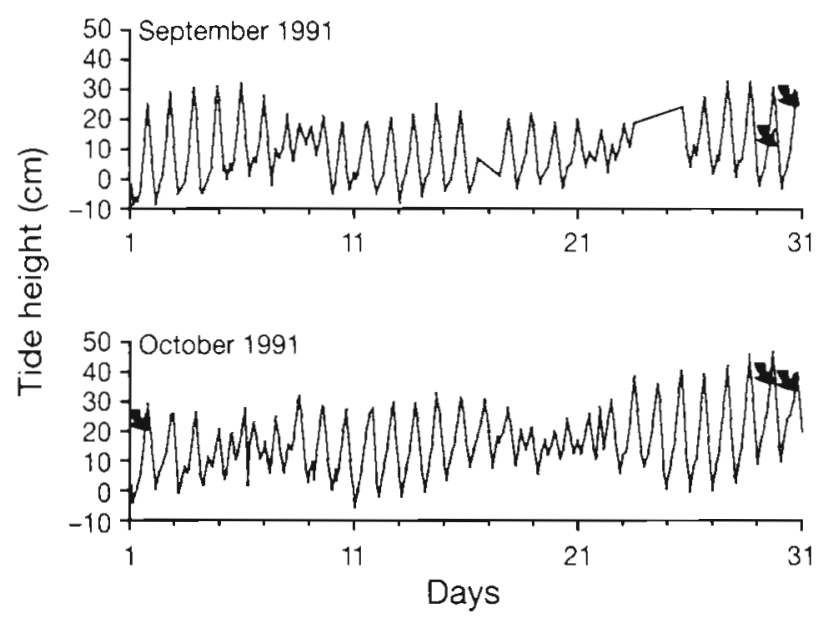

Fig. 8. Montastrea annularis. Spawning observations plotted against the Curaçao tidal cycle, September and October 1991 (Willemstad area). Arrows indicate observed spawning event

warmest local period (Fig. 7A). Apart from the month in which spawning occurred, spawning was consistent concerning days after the full moon (ca 6 to $8 \mathrm{~d}$ ), and time after sunset (ca 2 to $3 \mathrm{~h}$ ). Tidal amplitude, on the other hand, may not be a primary spawning cue in this species, since spawning occurred on an intermediate tidal range during falling tides in this study, whereas in Bermuda spawning was reported during neap tides (Wyers et al. 1991).

Differences in seawater temperature as possible explanation for the delayed reproduction on Curaçao and Bonaire can be explained from the position of the islands in relation to the tropics (Fig. 7B). The annual maximum temperature on Curaçao is reached later, as a consequence of a reduction in the effective solar energy during June and July when the sun has passed the island moving towards the northern tropics. The climatic anomalies of the islands, viz. trade wind and low annual rainfall (Trewarther 1981), may have a minor impact.

The question is what controls the initiation time of gametogenesis or period of development, since major cues are consistent. In most corals gametogenesis takes place during seasonal warm(ing) periods (Fadlallah 1983, Shlesinger \& Loya 1985, Richmond \& Hunter 1990, Glynn et al. 1991). My results from Curaçao agree with data from Puerto Rico (Szmant 1991) concerning the time-span of gametic development, but the initiation period of gametogenesis was slightly different. The first indications of reproductive cells (stemcells) were seen at the end of May on Curaçao, while spawning took place in September. In Puerto Rico gametogenic activity as well as spawning were about 1 mo earlier. A major problem is the recognition of the first developmental stage of gametogenesis. In this paper the stem-cell concept was followed (Lajtha 1983). Stem-cells are thought to have an extensive selfmaintaining capacity and a potential for differentiation (Lajtha 1983). Investigations on Hydra species showed that their interstitial cells are multipotent uncommitted stem-cells which can give rise to nerves and nematocytes or eggs and sperm in sexually active animals (David 1983). In coral research the concept was used by Delvoye (1988). According to Lajtha (1983) nothing is known about the stimuli or mechanisms inducing further differentiation in stem-cells, but he believes some genetic re-programming is involved. In this respect a biological rhythm, i.e. endogenous time clock, circannual in the case of Montastrea annularis, may be considered. Especially long-lived organisms that inhabit changing environments are expected to have evolved control systems that adapt them to annual fluctuations of biologically significant factors (Gwinner 1986). Involvement of an endogenous calendar in the initiation of gametogenesis was suggested for Echinodermata (Pearse et al. 1986). Initiation of spermatogenesis in hermaphrodites may also be triggered by an internal mechanism, such as egg maturation.

The availability of mature sperm [a maximum of $32 \%$ of the examined colonies ( $n \geq 15$ ) carried mature sperm] may partly explain low recruitment success of Montastrea annularis (Bak \& Engel 1979). In comparison, mature ova were evident in 68 to $80 \%$ of the examined colonies in the week of the spawning.

It is obvious (Table 1) that most spawning observations consist of a 'split-spawning', i.e. spawning over consecutive moon cycles. This phenomenon is also reported for spawning events on the Great Barrier Reef (Willis et al. 1985) and was explained as the effect of a relatively early full moon. The most intense spawning episodes on Curaçao in 1991 and 1992 took place about 1 wk after full moon occurred on 23 and 12 September, respectively, and were followed by a minor spawning in the consecutive months. In contrast in 1993 the full moon appeared fairly late; consequently, a minor spawning was observed after the 31 August full moon, followed by a more intense spawning following the full moon on 30 September. This data suggests that spawning intensity is affected by a relatively early or late full moon, but not the existence of the phenomenon split-spawning. This may rather be a result of ecologically relevant factors, such as minimizing the effect of a single catastrophic event (Richmond \& Hunter 1990), or providing a second chance for not fully reproductive or stressed colonies. Small colonies $\left(<300 \mathrm{~cm}^{2}\right)$ often carried numerous undeveloped eggs at the time of first spawning episode (Van Veghel \& Kahmann 1994); this also was observed in regenerating colonies (Van Veghel \& Bak 1994). 
In conclusion, the 3 coexisting morphotypes of the dominant Caribbean reef coral Montastrea annularis have a synchronized gametogenesis, gametes mature on the same lunar phases, and spawning time and behavior are the same. This is in contrast to other life history characteristics - genetic composition, morphology, morphometrics, intraspecific competition, growth and regeneration - in which at least 1 morphotype shows significant differences in comparisons with the other 2 (Tomascik 1990, Knowlton et al. 1992, Van Veghel \& Bak 1993, 1994).

Acknowledgements. I thank all 75 local divers who participated in the '1991 Coral Spawning Event'. Thanks to my diving buddies Aubrey Tiel, Frank Isabella and Oscar Frans. John Bradshaw, Janice Pourier, Gerard Nieuwland, Jan Vermeulen and Laurent Delvoye are acknowledged for their help with the histological work. Valuable information on spawning observations was provided by: Gert-Jan Gast, Margriet Kielman, Paul Hoetjes, Philip Butler, Kalli de Meyer (Bonaire) and Tom van 't Hof (Saba). The CARMABI Institute, the University of the Netherlands Antilles and Curaçao Port Authorities gave logistic support. Rolf P. M. Bak and 2 anonymous reviewers provided valuable comments on the manuscript. This research was supported financially by the Institute of Taxonomic Zoology of the University of Amsterdam.

\section{LITERATURE CITED}

Babcock, R. C., Bull, G. D., Harrison, P. L., Heyward, A. J., Oliver, J. K., Wallace, C. C., Willis, B. L. (1986). Synchronous spawning of 105 scleractinian coral species on the Great Barrier Reef. Mar. Biol. 90: 379-394

Bak, R. P. M. (1975). Ecological aspects of the distribution of reef corals in the Netherlands Antilles. Bijdr. Dierk. 45: $181-190$

Bak, R. P. M., Engel, M. S. (1979). Distribution, abundance and survival of juvenile hermatypic corals (Scleractinia) and the importance of life history strategies in the parent coral community. Mar. Biol. 54: 341-352

Balinsky, B. J. (1975). An introduction to embryology. W. B. Saunders Company, Philadelphia, p. 16-66

Bloom, W., Fawcett, D. W. (1975). A textbook of histology. W. B. Saunders Company, Philadelphia, p. 807-846

Burck, H. C. (1966). Histologische Technik. Georg Thieme Verlag, Stuttgart, p. 205

David, C. N. (1983). Stem cell proliferation and differentiation in Hydra. In: Potten, C. S. (ed.) Stem cells. Their identification and characterization. Churchill, Livingstone, p. 12-27

Delvoye, L. (1988). Gametogenesis and gametogenic cycles in Agaricia agaricites (L) and Agancia humilis Verrill and notes on gametogenesis in Madracis mirabilis (Duch. \& Mich.) (Scleractinia). Studies in honour of Dr. Pieter Wagenaar Hummelinck. Foundation for Scientific Research in Surinam and the Netherlands Antilles, Amsterdam, no. 123: $101-134$

Fadlallah, Y. H. (1983). Sexual reproduction, development and larval biology in scleractinan corals. A review. Coral Reefs 2: $129-150$

Gittings, S. R., Boland, G. S., Deslarzes, K. J. P., Combs, C., Holland, B. S., Bright, T J. (1992). Mass spawning and reproductive viability of reef corals at the East Flower Gar- den Bank, Northwest Gulf of Mexico. Bull. mar. Sci. 51(3): $420-428$

Glynn, P. W., Gassman, N. J., Eakin, C. M., Cortes, J., Smith, D. B., Guzman, H. M. (1991). Reef coral reproduction in the eastern Pacific: Costa Rica, Panama and Galapagos (Ecuador). I. Pocilloporidae. Mar. Biol. 109: 355-368

Goreau, T J., Hayes, R. L., Clark, J. W., Basta, D. J., Robertson, C. N. (1991). Elevated satellite sea surface temperatures correlate with Caribbean reef bleaching. NOAA Technical Report N.O.S. \#137: 1-60

Gwinner, E. (1986). Circannual rhythms. Endogenous annual clocks in the organisation of seasonal processes. SpringerVerlag, Berlin, p. 154

Harrison, P. L., Babcock, R. C., Bull, G. D., Oliver, J. K., Wallace, C. C., Willis, B. L. (1984). Mass spawning in tropical reef corals. Science 223: 1186-1189

Harrison, P. L., Wallace, C. C. (1990). Reproduction, dispersal and recruitment of scleractinian corals. In: Dubinsky, $Z$. (ed.) Ecosystems of the world 25. Coral reefs. Elsevier, Amsterdam, p. 133-207

Johnson, K. G. (1992). Synchronous planulation of Manicina areolata (Scleractinia) with lunar periodicity. Mar. Ecol. Prog. Ser. 87: 265-273

Jokiel, P. L. (1985). Lunar periodicity of planula release in the reef coral Pocillopora damicornis in relation to various environmental factors. Proc. 5th int. coral Reef Congr. 4: $307-312$

Knowlton, N., Weil, E., Weigt, L. A., Guzmán, H. (1992) Sibling species in Montastrea annularis, coral bleaching, and the coral climate record. Science 255: 330-332

Lajtha, L. G. (1983). Stem cell concepts. In: Potten, C. S (ed.) Stem cells. Their identification and characterization. Churchill, Livingstone, p. 1-9

List, R. J. (1951). Smithsonian meteorological tables. Smithsonian Institute, Washington, p. 495-496

Mayr, E. (1970). Populations, species and evolution. Harvard University Press, Cambridge, p. 453

Muir, P. R. (1984). Periodicity and asexual planulae production in Pocillopora damicornis (Linneaus) at Magnetic Island. Thesis, James Cook University of North Queensland, Townsville, p. 58

Ogden, J. C., Gladfelter, E. H. (1986). Caribbean coastal marine productivity (CARICOMP). UNESCO Rep. mar. Sci., No. 410

Pearse, J. S., Eernisse, D. J., Pearse, V. B., Beauchamp, K. A. (1986). Photoperiodic regulation of gametogenesis in sea stars, with evidence for an annual calendar independent of fixed daylength. Am. Zool. 26: 417-431

Richmond, R. H., Hunter, C. L. (1990). Reproduction and recruitment of corals: comparison among the Caribbean, the Tropical Pacific, and the Red Sea. Mar. Ecol. Prog. Ser. 60: $185-203$

Rinkevich, B., Loya, Y (1979). The reproduction of the Red Sea coral Stylophora pistillata. II. Synchronization in breeding and seasonality of planulae shedding. Mar. Ecol. Prog. Ser. 1. 145-152

Shlesinger, Y., Loya, Y. (1985). Coral community reproductive patterns: Red Sea versus the Great Barrier Reef. Science 228: $1333-1335$

Sokal, R. R., Rohlf, F. J. (1981). Biometry. W. H. Freeman and Co., New York

Soong, K. (1990). Reproduction of colonial reef corals: individuality of coral colonies and colony size related characters. Ph.D. thesis, University of Texas, Austin, p. 138

Soong, K. (1991). Sexual reproduction patterns of shallowwater reef corals in Panama. Bull. mar. Sci. 49(3): 832-846

Szmant, A. M. (1986). Reproductive ecology of Caribbean reef corals. Coral Reefs 3: $149-156$ 
Szmant, A. M. (1991). Sexual reproduction by the Caribbean reef corals Montastrea annularis and Montastrea cavernosa. Mar. Ecol. Prog. Ser 74: 13-25

Szmant, A. M., Gassman, N. J (1990). The effects of prolonged 'bleaching' on the tissue biomass and reproduction of the reef coral Montastrea annularis. Coral Reefs 8 : $217-224$

Szmant-Froelich, A. (1985). The effect of colony size on the reproduction ability of the Caribbean coral Montastrea annularis. Proc. 5th int. coral Reef Symp. 4: 295-300

Tomascik, T. (1990). Growth rates of two morphotypes of Montastrea annularis along a eutrophication gradient, Barbados, W.I. Mar. Pollut. Bull. 21(8): 376-381

Trewarther, G. T. (1981). The earth's problem climates. University of Wisconsin Press, Madison, p. 66-73

Van Duyl, F. C. (1985). Atlas of the living reef of Curaçao and Bonaire (Netherlands Antilles), Vol. 117. Foundation for Scientific Research in Surinam and the Netherlands Antilles, Utrecht, p. 37

Van Moorsel, G. W. N. M. (1983). Reproductive strategies in two closely related stony corals (Agaricia, Scleractinia). Mar. Ecol. Prog. Ser. 13: 273-283

Van Veghel, M. L. J. (1993). Multiple species spawning on Curaçao. Bull. mar. Sci. 52(3): 1017-1021

Van Veghel, M. L. J., Bak, R. P. M. (1993). Intraspecific variation of a dominant Caribbean reef building coral, Montastrea annularis: genetic, behavioral and morphometric aspects. Mar. Ecol. Prog. Ser. 92: 255-265

This article was submitted to the editor
Van Veghel, M. L. J., Bak, R. P. M. (1994), Reproductive characteristics of the polymorphic Caribbean reef building coral Montastrea annularis. III. Reproduction in damaged and regenerating colonies. Mar. Ecol. Prog. Ser. 109: 229-233

Van Veghel, M. L. J., Kahmann, M. E. H. (1994). Reproductive characteristics of the polymorphic Caribbean reef building coral Montastrea annularis. II. Fecundity and colony structure. Mar. Ecol. Prog. Ser 109: 221-227

Ward, S. (1992). Evidence for broadcast spawning as well as brooding in the scleractinian coral Pocillopora damicornis. Mar. Biol. 112: 641-646

Weil, E., Knowlton, N. (1994). A multi-character analysis of the Caribbean coral Montastrea annularis (Ellis \& Solander, 1786) and its two sibling species, $M$. faveolata (Ellis \& Solander, 1786) and M. franksi (Gregory, 1895). Bull. mar. Sci. (in press)

Willis, B. L., Babcock, R. C., Harrison, P. L., Oliver, J. K., Wallace, C. C. (1985). Patterns in the mass spawning of corals on the Great Barrier Reef from 1981 to 1984 . Proc. 5th int. coral Reef Congr. 4: 343-348

Willis, B. L., Babcock, R. C., Hairrison, P. L., Wallace, C. C. (1992). Experimental evidence of hybridization in reef corals involved in mass spawning events. Abstracts 7 th int. coral Reef Symp., Guam, p. 109

Wyers, S. C., Barnes, H. S., Smith, S. R. (1991). Spawning of hermatypic corals in Bermuda: a pilot study. Hydrobiologia 216/217: 109-116

Manuscript first received: August 18, 1993

Revised version accepted: March 30, 1994 